\title{
NEW DIRECTIONS IN ETANDEM: AN EXPANDED VISION OF CAPABILITIES AND PRACTICES
}

\author{
Novos caminhos em eTandem: uma visão expandida de \\ capacidades e práticas
}

\author{
Michael MARSH-SOLOWAY' \\ Olivier Michel DELERS²
}

\begin{abstract}
Autonomy and reciprocity, two central tenets of eTandem, are not ideologically neutral terms. In light of new technological opportunities and pedagogical directions in higher education, current formulations of these concepts are perhaps too narrow to accommodate the full range of collaborative activities available to instructors and students. For better or worse, education assumes a significant and definitive role in the market economy. The public-private distinction is not an actual binary: it is more accurately understood as a spectrum, and educational institutions function dually as hybrid recipients and benefactors of economic activity. eTandem is an excellent foundation, but teachers should not feel limited in its scope and purview. By reflecting on instructional activity and observation in Arabic, Italian, and Spanish courses at the University of Richmond, this article presents different interpretations of eTandem. The traditional model can be enhanced with related tools and methodologies to engage students more deeply, and challenge them to push the boundaries of their language, abilities, and knowledge. While additional SLA research would be needed to confirm the transference of learning outcomes of both models through comparative evaluative metrics, this article outlines ideas for instructors to commence new directions in eTandem, and consider improvements to long-standing practices.
\end{abstract}

Keywords $\mid$ eTandem. Autonomy. Reciprocity. Private Sector Partners. L2 Instructional Technology.
Resumo | Autonomia e reciprocidade, dois princípios centrais do eTandem, não são termos ideologicamente neutros. Com o advento de novas oportunidades tecnológicas e diretrizes pedagógicas na educação superior, as formulações atuais destes conceitos talvez sejam muito limitadas para acomodar todas as possibilidades de atividades colaborativas disponíveis aos professores e alunos. Bem ou mal, a educação assume um papel significativo e definitivo na economia de mercado. A distinção entre o público e o privado não é, de fato, binária: deve ser entendida como um espectro, e as instituições educacionais funcionam duplamente como recipientes híbridos e benfeitores de atividades econômicas. O eTandem é uma excelente base, mas os professores não deveriam limitar-se somente ao seu escopo. Através da reflexão sobre as atividades educacionais e a observação dos cursos de árabe, italiano e espanhol na Universidade de Richmond, este artigo apresenta interpretações diferentes de eTandem. O modelo tradicional pode ser incrementado com ferramentas e metodologias que motivem e desafiem os alunos a fim de expandir seus horizontes linguísticos, suas habilidades e conhecimento. Embora sejam necessárias mais pesquisas em aprendizagem de segunda língua para confirmar os resultados de aprendizagem dos dois modelos através de uma avaliação, este artigo propõe ideias para que os professores iniciem novos caminhos em eTandem e considerem inovações para práticas estabelecidas.

Palavras-chave | Reciprocidade. Parceiros do setor privado. Tecnologia na aprendizagem de segunda língua.

\footnotetext{
1 Marsh-Soloway. University of Richmond. E-mail: mmarshso@richmond.edu. ORCID ID: https://orcid. org/0000-0002-3086-9001
}

2 Delers. University of Richmond. E-mail: odelers@richmond.edu. ORCID ID: https://orcid.org/0000-00034412-3478 
- New directions in etandem: an expanded vision of capabilities and practices

\section{Introduction}

The three core principles of teletandem established by João Telles, drawing on the foundational definitions of tandem pedagogical models by Helmut Brammerts (2002), include autonomy, reciprocity, and separate use of both languages (TELLES, 2015; BRAMMERTS, 2002). By providing students with "a virtual, collaborative and autonomous context...in which two students help each other to learn their own languages (or language of proficiency)," instructors involved in tandem learning initiatives seek to develop partnerships with other institutions, usually across national borders, to facilitate productive exchanges. These activities tend to be oriented toward the common goals of promoting increased linguistic ability, intercultural competence, and multi-perspective debate. For instance, Brazilian students can practice their English with American peers. By comparing American culture with their own, they have the opportunity to reflect on their own identity, and thus to develop their intercultural skills. In turn, American students gain the unique chance to speak with native speakers of Portuguese, and to expand their horizons by learning about a culture with which they could not otherwise engage at a deeper, more 'authentic' level (GILMORE, 2007; MISHAN, 2005).

Authenticity is a topic that foreign language instructors need to engage critically, since there are often gaps between materials presented in textbooks and content produced by or familiar to native speakers. The situation is complicated, moreover, by the perceived function of English as a lingua franca, student motivation related to these concerns, and the difficulty of texts and activities corresponding to course levels. eTandem is an instructional practice worthy of reduplication, but the theoretical parameters of associated practices should be flexible enough to accommodate exciting opportunities for pedagogical experimentation and growth. As the 2018 IMFLIT (International Meeting on Foreign Language Learning in Tandem) conference hosted at the University of Miami demonstrated, tandem learning has made possible the creation of a large network of practitioners who speak the same pedagogical "language," and share a commitment to enhancing language and cultural learning in different parts of the world, across diverse disciplinary arenas of inquiry.

In describing the overarching pedagogical model, instructors and practitioners tend to use the terms of 'teletandem,' 'eTandem,' and 'learning in tandem' interchangeably. This practice has also been adopted by Telles (2015), and this article upholds the same convention. The progression of rhetoric used to refer to exchanges between students at different institutions through online collaborations has undergone marked transformations as technology and theory have brought to light new directions and realizations for 
communicative opportunities. The multiplicity of nomenclatures and parlances used to describe the practice underscores the evolving nature of the instructional method as a whole, and speaks to the fluidity of forms that fall under its operative umbrella of classification.

Autonomy and reciprocity, two central tenets of eTandem, are not ideologically neutral terms. Firstly, from the perspective of autonomy, the pedagogical model stresses a spontaneous conversational setting, where students get to "choose what to talk about, and to manage their own learning by giving them the freedom to choose their favorite resources and activities" (TELLES, 2015). The model presumes that tandem learning exchanges simultaneously contribute in a mutually beneficial manner to the objectives of both instructors. Taking backward-course design directives into account, even within a single university, department, or program, it is exceedingly difficult to find two courses with identical goals, activities, assessments, and learning outcomes. This prospect becomes even harder in coordinating curricular connections between two institutions in different countries and education systems.

In short, seemingly no two courses have the exact same objectives and metrics to evaluate success. While students undoubtedly enjoy the increased 'freedom' of autonomous exchanges, the open-ended nature of theircommunication requires extensive "orientation" and "mediation" sessions to coordinate the activities toward common goals, and even then, there is no telling if the eTandem will serve to enhance specific outcomes of each course. Aside from Telles, A.K. Elstermann also endorses "orientation" and "mediation," but too little is mentioned about the difficulties of facilitating the convergence of goals in different courses, departments, and institutions (ELSTERMANN, 2017). The disciplinary assignments of the two courses may be too far afield for this mutual benefit to transpire efficiently. For instance, will an ESL course taught in Mexico necessarily align with a second-year Spanish course in the US? What about the correlation, moreover, between cultural subjects and language courses? While there will undoubtedly be certain synergies and overlaps between the two instructional contexts combined separately in tandem, direct contributions to more specific course objectives, including critical thinking skills, qualitative reasoning, abstract analysis, and progress towards proficiency benchmarks relative to individualized learning plans, student portfolios, and curricular standards will be difficult to articulate, let alone successfully fulfill.

The notion of reciprocity also entails a wide range of manifestations. The methodological premise presumes an equal exchange, in which the giver is also a receiver of language instruction, and vice versa (VASSALLO; TELLES, 2006). Everyone gains from the relationship, precisely because it does not involve a monetary transaction, and because 
- New directions in etandem: an expanded vision of capabilities and practices

no participants assume a direct financial or material obligation to their partner(s). When it works well, tandem learning can function as an economic equalizer of sorts, facilitating non-commercial exchanges between and within the West and Global South. Aside from cost-prohibitive and time-intensive opportunities for direct contact through travel, tandem learning represents one of the only ways to effectively connect students in different parts of the world, empowering them to forge relationships and engage global dialogues in the face of stark material disparities. By providing free educational exchanges, eTandem provides an invaluable service in the context of communication and networking systems in an imperfect post-colonial world. Aside from representing a pedagogical principle, the ascribed vision of "reciprocity," consequently, also embodies a political ideal.

Advances in videoconferencing technologies have made both free and for-profit exchanges viable, but only the latter assumes sustainability as a dynamic hybrid businesseducational model. For-profit sites more effectively accommodate the busy schedules of instructors by offering on-demand tandem exchanges, providing adaptable contexts for improved inclusion in established course goals and assignments, and offering technically compatible interfaces for documenting activities and learning outcomes in existing learning management systems, such as Blackboard, Canvas, Sakai, etc., relative to the retention, analysis, and ongoing progression of collected exchanges. There are numerous pedagogical directions that can both advance and benefit from the objectives of eTandem. By providing a section detailing possibilities for technological experimental and growth, this article outlines ways in which eTandem could easily coincide with ePortfolios, project-based language learning, intensive thematic instruction, and digital storytelling. In a for-profit exchange, students from the paying institution retain the right to the original recordings, whereas in a free, fully 'reciprocal' model they do not, and future access to the recordings hinges on the mutual media consent release of both parties. This puts limitations on the kind of work students can do after the associated exchanges in terms of integrating eTandem activities into other course objectives, assignments, and assessments.

Within the strict parameters of the theoretical basis set forth by Telles (2015) and Brammerts (2002), no tandem learning is possible if there is no reciprocity and the relationship between two parties becomes transactional. In practice, however, the powerful methodology and pedagogical goals that underlie tandem learning can still apply to these new language exchanges. For instance, even when the exchange is facilitated by a private company, students are still given the chance to interact with a native speaker in real time and on their own terms. They can also reflect productively on the nature of the bond that they are forming with another person and, as we would like to argue in this article, think about the tension between cultural dialogue, socioeconomic perspectives 
on global events, and language learning through broadened exposure to representatives of different dialects and regions from the target subject. There is another aspect of online video language services to consider here. For instructors concerned about the time commitment of setting up tandem relationships and the scheduling and technological difficulties inherent to these exchanges, for-profit companies provide a turnkey product, with a low threshold to start experimenting with high-impact practices, and the possibility to discontinue the relationship quickly if it does not work well. Paradoxically perhaps, these new services hold a potential to make language e-learning more widespread, and to encourage instructors to move eventually to the more traditional tandem model involving free exchanges.

Over the last five years or so, many new companies from the private-sector have started offering language learning services online, often by selling the services of a native speaker of a particular language to students learning that language. Examples of these websites include TalkAbroad, iTalki, Tandem, LingoGlobe, Speaky, Wespeke, and Boomalang, just to name a few of the more popular interfaces. In these exchanges, one side buys a service while the other receives compensation for it - and a private company takes a cut as an intermediary for coordinating the collaborative meetings, providing an improved VOIP (Voice over Internet Protocol) technical interface, as well as preserving recordings of all assignments and interactions. Since these companies work with multiple universities, they could eventually provide qualitative and quantitative feedback of student progress, abilities, and activity models relative to national and international data sets.

Despite the proliferation of these services, which in turn indicate the increased popularity of the for-profit model in higher education, Telles argues that they do not adequately exemplify the model of teletandem, on the grounds that "these initiatives do not offer links between institutions, [and] the three distinct modes of implementation have an impact on the ways, on the responsibility, and on the seriousness with which the students consider the practice" (TELLES, 2015). This article challenges the notion that for-profit language services could be viewed as completely lacking autonomy and reciprocity, following the formulation by Telles. The realization of these key principles in paid exchanges does not occur as a binary, e.g., off or on, yes or no, present or absent. We argue that it is more appropriate to accommodate varying permutations of these notions along the dynamic private-public spectrum, which corresponds more realistically to the financial composition and role of higher education as a whole in the twenty-first century.

Our goal in this paper is two-fold: first, we will describe and reflect upon pilot programs implemented in the Departments of Languages, Literatures, and Cultures (LLC) and Latin American, Latino, and Iberian Studies (LALIS) at the University of Richmond 
- New directions in etandem: an expanded vision of capabilities and practices

that seek to achieve pedagogical outcomes similar to those made possible by eTandem learning. Second, we would like to consider eTandem as a set of pedagogical practices, which while grounded in notions of dialogue, autonomy, reciprocity, performativity, and discourse analysis, encompass a much broader set of activities than those mentioned by João Telles in his keynote address at the IMFLIT conference (TELLES, 2018). This article particularly explores re-evaluations of autonomy, reciprocity, and the separation of languages as areas that could benefit from expanded pedagogical application and practices. In light of changing technology, authentic interactions between different cultural perspectives, and linguistic research, eTandem is an evolving model that benefits from the ongoing consideration of and experimentation by dedicated instructors, motivated students, and collaborative partners across both the private and public sectors to offer improved learning outcomes.

\section{Case Study 1: Traditional eTandem between UR and UAEH}

Throughout the spring of 2018, the Global Studio language lab helped to connect an intensive second-year Spanish course, LAIS 221, at the University of Richmond with a series of English courses taught at Universidad Autónoma del Estado de Hidalgo (UAEH). The open-ended discourses provided an enjoyable language exchange that convened on two separate occasions, once on February 16, and again on April 5. In the first exchange, students connected in an open format to discuss any topic of their choosing. Most discussed details about their daily routines, college activities, social networks, and families. Subsequently, in the second connection, students explored the more complicated themes of politics, the media, and fake news. Based on the results from a brief poll conducted via a simple Google Form in April 2018, 11 of 15 the UR students evaluated the enjoyment and usefulness of the activities at an 8 or higher on a scale from 1-10. While the students successfully completed the exercises, coordinating the event did not unfold without its fair share of difficulties.

To preserve the privacy of students in the exchange, we needed first to create dummy Skype accounts to connect with our counterparts at UAEH. Due to increased security measures, Microsoft (the parent company of Skype) now requires cell phone numbers and email addresses from individual subscribers to both place and receive calls. Fortunately, our colleagues at UAEH had more experience in coordinating these connections, and they were able to lend us passwords and accounts to conduct the calls with greater anonymity. If there are a limited number of generic Skype accounts in circulation for eTandem purposes, this challenge could prove an insurmountable obstacle 
for U.S. institutions bound by FERPA (Family Educational Rights and Privacy Act) compliance regulations, which stipulate the law-binding needed to protect and prevent student data from being shared involuntarily. Asking students to use their personal accounts in a mandatory course exercise coordinated in conjunction with another institution could unwittingly expose universities, departments, and coordinating faculty to lawsuits and liabilities.

Leading up to the calls, moreover, it proved necessary to conduct a lengthy test of the bandwidth capabilities and audiovisual resources in the Global Studio lab. As a technical interface, Skype is a fairly robust program that requires a great deal of bandwidth to conduct a conversation without delays and splotchy signals. Holding calls from 19 computers simultaneously tends to put a drain on the local network. Including the separate Skype Call Recorder interface to automate the process of capturing the exchanges in a meaningful pedagogical manner involves numerous moving technical components.

Prior to the eTandem exchanges, the associated orientation, mediation, and logistics of pairing students between the two schools proved effective, but required patience, understanding, and flexibility. After introducing the instructors at both UR and $\mathrm{UAEH}$, our connected group of lab support partners depended on their correspondence to establish themes, guidelines, and expectations. The two-hour difference between Hidalgo and Richmond evoked a modicum of stress, especially as late arrivals and unexpected absences made it necessary to make last-minute adjustments. Due to incongruous enrollment figures, students ended up working in groups of threes, and we sometimes adjusted partners mid-conversation to help pair-up students who arrived after the exchange had already begun. Additionally, while explaining guidelines to the students regarding which language to start with, suitable discussion topics, and frameworks for reflection, calls started to come in around the lab, which interrupted initial discussions. While some students requested to be paired up with a specific partner from the first exchange in the second connection, it became exceedingly difficult to determine at the last minute where these students were sitting, and which anonymous account they were using to participate in the call.

This case study shows the difficulty of implementing a traditional eTandem partnership. Even with good will and great effort on the part of the lab coordinators and instructors to facilitate successful exchanges, it is hard to preserve the core elements of the tandem model when each group's needs are not perfectly aligned. Here, for instance, students had no real individualized autonomy since they worked in small groups and could not in most cases develop a long-term relationship with their tandem peers. As we saw, eTandem practitioners also have to navigate constantly shifting technological and 
- New directions in etandem: an expanded vision of capabilities and practices

legal landscapes. A sudden drop in bandwidth could endanger months of planning. In the United States, in particular, new laws protecting student privacy could put the very notion of autonomous and reciprocal exchange at risk. Instructors could increasingly have to prepare waivers for their classes to sign in order not to run afoul of state or federal rules. Finally, it is clear that the idea of reciprocity cannot conceal the fact that setting up the logistics of exchange, orienting staff and students, and troubleshooting issues is extremely labor intensive and stressful. In many cases, that labor comes on top of other responsibilities and is not adequately compensated. Too often, the compensation comes from the pleasure of connecting students with each other, even when adjustments and compromises need to be made. The eTandem exchanges between UAEH and UR students proved successful, and most of the students indicated that they would enjoy communicating with their partners in subsequent independently coordinated conversations of their own volition. For the most part, the students all got along, they enjoyed learning about each other, and they exchanged meaningful, authentic details about their cultural contexts.

\section{Case Study 2: Teaching Arabic Remotely}

Technological innovation in the field of video-conferencing has greatly simplified the logistics involved in teaching remotely and has lowered the cost of access for many institutions. It has created new opportunities for American universities to offer beginning courses in languages that could not otherwise be taught on campus. This is particularly true for small liberal arts colleges: with enrollment topping at 3000 students, it is financially difficult to staff programs in less-commonly taught languages since the number of interested students would be too low to justify hiring a full-time faculty, or sometimes even an adjunct instructor. Two organizations to which the University of Richmond belongs, the Virginia Foundation for Independent Colleges (VFIC) and the Associated College of the South (ACS) have given their members support and incentives to implement remote teaching programs.

Over the past four years, our Arabic Studies program has provided remote access for our beginning and intermediate courses $(101,102,201,202)$ to students at other Virginia colleges. The number of enrolled students is typically low (with a maximum of two students per course) and not all courses have remote students. The courses meet four times a week. Students from partner institutions attend every class session remotely using either the Cisco Polycom System or Lifesize, depending on the technical resources and infrastructure of institutions supporting remote students. The classroom is equipped with two cameras and built-in microphones. Our language resource center, the Global Studio, 
hires one student to operate the cameras and troubleshoot any technological difficulties. The instructor is thus free to focus on his lesson plan and teach as he normally would in a non-remote setting. Remote students have access to the same resources as their peers: they take part in in-class activities, are asked to participate in group and individual assignments, and can ask questions when necessary. The instructor also offers office hours by Skype and travels to the partner school to meet the students in person when possible.

In our experience, remote teaching facilitates the implementation of two new types of tandem connections. First, the remote student and the instructor work in tandem in a unique teaching and learning relationship. The goal is to preserve to the greatest extent possible all the core elements of the class and to create a powerful relationship built on regular online interactions between teacher and learner. Each party is giving and receiving, in very much the same way that both teachers and students give and receive in a regular classroom. The teacher shares knowledge and puts into place activities and assessments meant to maximize the acquisition of communicative skills. In exchange, she is compensated for her labor but also observes the student's intellectual growth and language gains. Students are on the receiving hand of the teacher's work, of course, but they also fulfill their part of an implicit contract by following instructions and working diligently in and outside of class. Remote teaching, because it is not a "standard" way of learning, lays bare the reciprocal nature of this relationship for students and teachers alike and allows them to think critically about what is happening in an exchange that we have come to take for granted.

The second type of tandem made possible by remote teaching lies in the possibility for several schools to help each other and coordinate their language offerings. As of now, our Arabic studies program is "giving" to other schools and, unfortunately, there are no University of Richmond students taking courses remotely at other institutions. But the ultimate goal is reciprocity. The ACS would very much like to support a network of remote offerings built on the strength of each member school. For instance, there is demand at the University of Richmond for Korean and Farsi and our students could benefit from programs offered at other universities. It would mean that language instructors would increasingly need to be trained in the pedagogy of remote teaching. Here, the theoretical and empirical research that has been conducted on tandem learning over the past decade could provide a foundation for developing training programs and doing further methodological research.

We wanted to include this second case study precisely because it broadens Telles' definition of eTandem. Here, we are no longer thinking just of student collaborations but of new modes of teaching made possible by technological advances. If autonomy and reciprocity are the two key components of eTandem learning, is it possible to achieve 
- New directions in etandem: an expanded vision of capabilities and practices

either in new contexts? Our provisional answer is that these goals are transferrable as long as the instructor draws the students' attention to the nature of the relationship being built and asks for a certain level of reflection in the learning process. This case study also sheds light on the fact that reciprocity should be considered at two different levels: reciprocity between institutions as they pull together resources for improving student outcomes, but also reciprocity in the human relationship that results from tandem-type activities. If that form of reciprocity takes place between students learning from each other, then it is also a central aspect of any teaching/learning relationship.

\section{Case Study 3: Intensive Second-Year Italian and TalkAbroad}

Exemplifying a kind of 'realpolitik' approach to eTandem, two other colleagues also experimented with remote collaborations between UR students and native speakers of Italian through the paid service of TalkAbroad. From a technical standpoint, TalkAbroad proved to be the easiest paid service to offer enrolled students based on its competitive rates, user-friendly student-instructor interface, and hassle free digital video conferencing platform. The service relies on WebRTC, a browser-based video communication tool that easily integrates with almost every operating system and hardware specifications without requiring a separate installation.

Two models of incorporating TalkAbroad activities were deployed into existing course frameworks. First, one instructor opted to coordinate a series of eight guest interview exercises across two sections of ITAL 221, for a total of sixteen exchanges, throughout the spring semester. Following this method, students prepared scaffolded assignments corresponding to grammatical and thematic units from the assigned textbook in preparation for authentic discussions on these topics with representatives of different Italian dialects and regions. The exercises encouraged students to consider course materials relative to their engagement and perception by actual Italian people in the dynamic, differentiated, and subjective experience of real life. Since the assignments were tailored to echo the progression of linguistic content presented in the textbook, the collaborative communicative exchanges coincided more seamlessly with identified course objectives, the gradual increase of proficiency benchmarks, and diverse learning outcomes deliberately designed by the instructor.

Leading up to the actual guest interviews, the UR teacher addressed preliminary questions about usage, semantics, and cultural norms, and encouraged the students to get personal in the conversation to explore topics related to opinion, belief, and personal experience. Students reported that they enjoyed the TalkAbroad exchanges, and the 
activities allowed them the unique opportunity to engage authentic interactions, which exposed them to different voices and perspectives in a collaborative environment that required less stress than parallel assignments completed on an individual basis. TalkAbroad also offers a user-friendly interface that automatically saves and distributes all assignment guidelines, recordings, and course commentary. Following the guest interviews, the instructor assigned students to reflect both on their abilities and the progression of the conversations in group discussion and in short written reflection compositions.

In the second model, a different Italian instructor opted to assign eight 15-minute TalkAbroad sessions to each student throughout the semester. This model was significantly more expensive and time-intensive, since it resulted in a total order of some 200 conversations. The instructor, who teaches jointly at Virginia Commonwealth University and the University of Richmond, was able to accommodate this cost by asking students to acquire a small TalkAbroad subscription in their initial textbook purchase at a reduced price offered at scale for the entire program, which was then also partially offset by department funds. Since the recordings compile automatically, the instructor would have immediate access to audio files of the exchanges, as well as brief native-speaker feedback provided by the TalkAbroad partners. After going through each of the individual fifteen-minute conversations, this instructor was able to deliver meticulous, granular recommendations for improvements, corrections, and suggestions to individual students in the act of spontaneous speech. While we did not conduct statistical analysis of how the presented feedback influenced learning outcomes, students indicated that the careful commentary by both their instructor and speaking partner contributed to new linguistic realizations, cultural understandings, and a heightened awareness of how to communicate more clearly with improved mistake correction and mental dexterity to adjust speech accordingly.

At first glance, a paid service like TalkAbroad would seem to be completely antithetical to the tandem model. Carefully constructing assignments, however, makes it possible to preserve many of the central characteristics of eTandem: listening to authentic material, being exposed to a variety of dialects, and benefitting from a collaborative environment. This model also invites a cost comparison between free traditional tandem initiatives and the services provided by for-profit companies. As we argued earlier, the labor involved in tandem relationships is often not properly assessed. With paid services, some of the labor is outsourced and is given an actual "market value." For instructors weary of the workload involved in launching a reciprocal tandem relationship with a partner abroad, services like TalkAbroad can serve as a first step in the right direction and as a way of experimenting with new pedagogies. 
- New directions in etandem: an expanded vision of capabilities and practices

Additional research would be needed to state whether deploying TalkAbroad in individual or group frameworks in second-year Italian produced better results relative to proficiency gains and course outcomes. For the time being, however, the options of using TalkAbroad for assignments by individual students and group interviews are not mutually exclusive. Instructors are welcome to experiment with both methods in a single course, and decide for themselves in light of the associated workload, ease of use, and student outcomes which model presents the more viable pedagogical practice to follow.

\section{Technology and New Directions for Autonomy and Reciprocity}

In light of the innovative and adaptable realizations of eTandem as an overarching pedagogical model, there exist many promising synergies that could arise from its combination with other technologies and methodologies to advance meaningful learning outcomes. For instance, eTandem provides unique frameworks that could simultaneously coincide with project-based language learning (PBLL) objectives, such as ePortfolio creation and collaborative digital storytelling. These initiatives could also benefit from multimedia engagement, including dubbing activities, subtitle creation, and diverse artistic representations of student expression in both synchronous and asynchronous exchanges. In a similar respect, instructors interested in group dynamics could deploy the Comprehensive Assessment of Team Member Effectiveness (CATME- http://info.catme. $\mathrm{org} / \mathrm{)}$ as a means of optimizing outcomes between individuals with different personality traits. A self-assessment by students would allow instructors to pair individuals between different universities toward specific goals and objectives.

The miracle of the internet readily provides a variety of tools, resources, and websites that facilitate the simultaneous creation and revision of dynamic multimedia materials. Students could create ePortfolio resources using free Google Sites, Docs, and Slides, or through institutional corporate models, such as Digication, WordPress, Ning, and Linguafolio. For media creation projects, students could compile clips, songs, and recordings simultaneously from completely different locations using shared interfaces in Adobe Spark, VoiceThread, FlipGrid, and GoReact. Similarly, the browser-based tools, SubtitleHorse, ClipFlair, EdPuzzle and PowToons serve to augment these activities with dictation, dubbing, interactive video exercises, and animations, depending on the scope and outcomes of the given eTandem exchange.

In this vein, aside from talking generally about a broad topic, students could be encouraged to exchange ideas freely in a creative mode that facilitates their shared compilation and retention of resources toward a specific production that would then 
represent the holistic sum of their different personalities, opinions, and ideas. Expressed in any range of multimedia formats, these collaborative models would allow students not only to talk obliquely about a given subject, but also to work together toward a common creative goal. How can they make their product, be it a video, blog, composition, collage, or bibliography compelling to the rest of the class? In the traditional eTandem model, how would students even know how their conversations relate to exchanges engaged by the rest of their classmates? Backchannel forums, polls, and surveys conducted via new websites like Padlet and Google Forms allow students to share both qualitative and quantitative feedback about their discussion with their peers, so they could then share important realizations, questions, and endeavors that came from the exchanges. Moreover, having a digital product that students could then share with their instructors and classmates preserves a creative record of the eTandem model relative to both the institutional memory of the participating courses and their sense of connection to their partner(s).

AsthetechnologicalmodelforeTandem continuesto expand and evolve, instructors, students, and lab support practitioners would be wise to evaluate the relative strengths and weaknesses of various VOIP technologies. Skype as a digital video conferencing platform lacks internal recording capabilities, features compression algorithms that strain limited bandwidth capabilities provided predominantly by university contracts with ISPs, such as Comcast, AT\&T, and Verizon. This is another important connection between education and the private sector. Universities rely on the internet for many of its most basic services. This often requires building a partnership with an established ISP to help students access and use the internet as a means of connecting to eTandem partners in other parts of the world. Aside from requiring users to adhere to stipulations that all accounts be registered to specific individuals, Skype as an interface also limits what the instructor can electronically monitor, deliver, and engage.

While this comment borders on dystopian science fiction, the fact that intelligence agencies retain legal access to monitor all unencrypted international VOIP connections comprises a valid concern for instructors. This is undoubtedly a perilous rabbit hole to go down, but this consideration is likely the root cause of the increased security measures that Microsoft recently required of users to register their cell phone numbers and email addresses to activate new Skype accounts. This understanding largely came to light in the revelations of the PRISM surveillance program from the Edward Snowden files, but the external monitoring also likely affects the associated technical reliability of the communicative interface. From the technical perspective of compression, moreover, Zoom handles the sizable audio and video inputs from student participants in a much 
- New directions in etandem: an expanded vision of capabilities and practices

more efficient manner than Skype, and the resulting communications transpire without frequent dropped calls and splotchy connections.

Compared to Skype, Zoom, presents a number of promising benefits. Using a paid institutional license, instructors can dole out accounts without tying them to a specific identity or phone number, can observe and record all interactions conducted in an eTandem environment from a single computer, and even facilitate the ease with which different students can be paired and re-paired in groups using its unique breakout room feature. Originally, Zoom was developed as a replacement for legacy PolyCom systems, but its efficiency as a webinar platform, lecture capture interface, and remote learning tool will likely exert immense competitive pressure on similar programs, including Blackboard Collaborate, Adobe Connect, PanOpto, Skype, Camtasia, Evaer, and Skype Call Recorder. Zoom effectively bundles the capabilities of all of these different tools in a single package, and will almost assuredly render previous models obsolete, albeit at the cost of an institutional license. Although access to Zoom requires an initial investment by a single institution, speaking partners invited to participate in the associated exchanges do not need to create or to have their own accounts. A single license is sufficient for both parties, allowing users to connect remotely via both web and phone interfaces.

\section{Expanded Notions of Reciprocity: Exploring New Engagement Strategies in eTandem}

The theoretical foundations of eTandem learning lend themselves to reevaluation. Conceptions of dialogue, autonomy, reciprocity, performativity, and discourse analysis espoused by the critical theorists that João Telles highlighted in his keynote address at the IMFLIT conference are all subject to debate (TELLES, 2018). The very foundation underlying the body of practices associated with eTandem could be interpreted relative to a variety of ideological positions and realizations. There are different ways of understanding the canonical instructional theories, philosophers, and authors to advance the legitimacy and effectiveness of pedagogical experimentation, involving permutations of the traditional eTandem model. While Telles has both conducted and cited compelling applied SLA research to promote the effectiveness of eTandem for increased intercultural competence, confidence, and reflection, the underlying theoretical basis of the presiding model is too narrow to accommodate the diverse realizations of successful learning outcomes that can result from combining and expanding its overarching scope in new pedagogical applications. 
The extensive writings of Mikhail Bakhtin (1895-1975), for instance, support numerous understandings of dialogism, autonomy and reciprocity (BAKHTIN, 1981). Despite his ostensible belonging to the Formalist School (the accursed ' $F$ ' word in critical theory), or the study of a text or phrase for its own sake on its own basis without any outside influence, Bakhtin invites increased inspection of his writings relative to the political realities of his life and times (BAKHTIN, 1978). As an advocate of polyphonic dialogue, or many voices in concert, like the setting of a language lab hosting eTandem activities, Bakhtin frames his theoretical perspective as an indirect subversive commentary of the monologic rhetoric of the repressive state (BAKHTIN, 1963; BAKHTIN, 1993). His writings need to be considered relative to the restricted political, economic, and social conditions of life under Soviet socialism (BENNET, 2003). If all endeavors serve the betterment of the state, then the realization of diverse, individualized, and free personas and voices within this society would come to undermine the congruence and unity of the central authority. While the Soviet Union was not devoid of artistic creativity, the expression of authentic beliefs and autonomous participation in the unofficial free market economy of ideas and goods persisted, albeit at the implied peril of participating actors. Consequently, the model of reciprocity presented by Bakhtin, which came to fruition in a context reminiscent of a totalitarian state, could be more completely understood as not dismissing monetary exchanges for educational and creative interactions.

Reciprocity, then, as the manifestation of an abstract ideal can still adhere to the position of Bakhtin in a variety of applied permutations without betraying its original Formalist basis. Several of the presentations at IMFLIT offered interfaces to improve the difficult scheduling and logistical details associated with coordinating eTandem interactions. The Mixxer project hosted at Dickinson College, and Panhora provide technical solutions for instructors and lab technicians to collaborate more efficiently with colleagues at other institutions across different time zones. While these efforts produce meaningful results in line with the ideal of free and direct reciprocity, the amount of energy and resources that goes into developing these ties is immense. The process is especially time-consuming, and it requires extensive investment, testing, and design mediation to develop, market, and deploy a digital platform that people will actually use. As a theoretical extreme, true reciprocity would allow students to coordinate their eTandem interactions with other students independently. The empirical reality, however, generally entails that the onus to set inter-institutional plans for pedagogical exercises and to navigate diverse technical resources falls primarily on the instructors. New technical resources empower students to remain at the center of these initiatives, and academics should not shy away from nor fear the private sector to facilitate these student-focused eTandem connections. 
- New directions in etandem: an expanded vision of capabilities and practices

\section{Conclusion}

Education almost assuredly coincides with the transmission of cost. In the United States, even public institutions receive only a partial amount of funding from the state, and the aggregate figure is trending downward nationally. While education is so much more than an economic commodity, the multifaceted services, resources, and expertise that serve to inspire students and help them to grow into mature professionals require great financial input. The cost of increased intellectual capital is immense, benefiting from diverse channels of investment through increased public and private funding. Even as states cut public spending on educational initiatives, private individuals, families, and companies are willing partners to cover the difference in cost. For better or worse, education assumes a significant and definitive role in the market economy. The publicprivate distinction is not an actual binary. It is more accurately understood as a spectrum, and all educational institutions exist dually as hybrid recipients and benefactors of both poles of economic activity.

eTandem is an extraordinarily effective approach to language instruction, but it is an evolving methodology that benefits from innovation and combination (as it were "in tandem") with new technologies and pedagogical philosophies. eTandem is an excellent foundation, but teachers should not feel limited in its scope and purview. Why restrict ourselves to the traditional model of eTandem, when the premise can be enhanced with related tools and methodologies to more deeply engage and challenge students to push the boundaries of their language, abilities, and knowledge? Although Telles should be applauded for pioneering best practices associated with eTandem, his view of what counts and what does not from the overarching pedagogical model is too narrow. Additional SLA research would be needed to support the hypothesis that for-profit services provide equal, if not better outcomes, qualified by means of descriptive experiences and impressions, and quantified by increased linguistic proficiency and intercultural competence for students than corresponding traditional models.

The authors of this article would like to express gratitude and appreciation to our colleagues Lorenza Marcin and Martin Sulzer-Reichel for their roles in collaboratively developing and delivering our presentation at 2018 IMFLIT. 


\section{References}

BAKHTIN, M. Problems of Dostoevsky's Poetics. Trans. Caryl Emerson. U of Minnesota Press, 1963.

BAKHTIN, M. The Dialogic Imagination. Trans. Caryl Emerson and Michael Holquist. Austin, TX: UT Austin Press, 1981.

BAKHTIN, M. Towards a Philosophy of the Act. Trans. V. Liapunov. Ed. M. Holquist. Austin: University of Texas Press, 1993.

BAKHTIN, M.; MEDVEDEV, P. M. The Formal Method in Literary Scholarship. Trans. A. J. Wehrle. Baltimore: The Johns Hopkins University Press, 1978.

BENNET, T. Formalism and Marxism. New York: Routledge, 2003.

BRAMMERTS, H. Aprendizagem autônoma de línguas em Tandem: desenvolvimento de um conceito. In: DELILLE, K. H.; FERREIRA, A. C. (ed.). Aprendizagem autônoma de línguas em Tandem. Lisbon: Colibri, 2002.

ELSTERMANN, A. Peer Group Mediation in Teletandem. Doctoral Thesis to the Department of Philology at Ruhr-Universität Bochum, 2017.

GILMORE, A. Authentic Materials and Authenticity in Foreign Language Learning, Language Teaching, v. 40, n. 2, p. 97-118, 2007.

MISHAN, F. Designing Authenticity into Language Learning Materials. Bristol, UK: Intellect, 2005.

TELLES, J. A Learning Foreign Languages in Teletandem: Resources and Strategies, D.E.L.T.A., v. 31, n. 3, p. 603-632, 2015.

TELLES, J. A. Keynote Speech at II IMFLIT, the International Meeting on Foreign Language Learning in Tandem. Miami, FL: University of Miami. 22 March 2018.

TELLES, J. A.; VASSALLO, M. L. Foreign Language Learning In-Tandem: Teletandem as an Alternative Proposal in CALLT, The EsPecialist, v. 27, n. 2, p. 189-212, 2006. 
- New directions in etandem: an expanded vision of capabilities and practices

TODOROV, T. Mikhail Bakhtin: The Dialogical Principle. Theory and History of Literature, Manchester: Manchester UP, v. 13, 1984.

VASSALLO, M. L.; TELLES, J. A. Foreign Language Learning In-Ttandem: Theoretical Principles and Research Principles and Research Perspectives, The EsPecialist, v. 27, n. 1, p. 83-118, 2006.

COMO CITAR ESTE ARTIGO: MARSH-SOLOWAY, Michael Abernathy; DELERS, Olivier Michel. New directions in eTandem: an expanded vision of capabilities and practices. Revista do GEL, v. 15, n. 3, p. 176-193, 2018. Disponível em: https://revistadogel.gel.org.br/

DOI: http://dx.doi.org/10.21165/gel.v15i3.2395

Submetido em: 12/11/2018 | Aceito em: 17/12/2018. 